\title{
ISSUES IN THE LEGAL FRAMEWORK OF INVALIDITY OF TRANSACTIONS IN UKRAINE
}

\author{
Iryna Dzera \\ Assoc. Prof. of Private Law Department, \\ Law Faculty, National University of Kyiv-Mohyla Academy \\ (Kyiv, Ukraine)
}

https://doi.org/10.33327/AJEE-18-2.1-a000010

Summary: 1. Introduction. - 2. Definition of a transaction and its specifics compared to other legal notions. -3 . Editorial and contextual issues with the provision of sec. 204 as to the presumption of legitimacy of a transaction. - 4. Terminological issues with the legal status of persons, that entered into an invalid transaction. - 5. Usage of the term 'invalidity' in other legal constructions. 6. Definition of an invalid transaction and its correlation with a void transaction. - 7. Grounds of invalidity of transactions: definition and issues in its framework. 8. Declaring transaction as unconcluded as a legal remedy. -9 . Conclusions.

This essay analyzes legal nature and grounds of nullity of transactions according to the civil legislation of Ukraine and modern civil law achievements. Correlation between invalid, void and illegal transactions is set. It establishes the specifics of invalid transactions, that demarks them from other similar legal categories. The essay discloses gaps and contradictions in the legislation of Ukraine, while pointing out different approaches of the application of law by the courts when it comes to the nullity of transactions, as well as offers solutions as to its improvement. The legal nature of articles of incorporation (articles of association, except for the articles of association of a partnership) is analyzed. And issue of possibility to use provisions as to invalidity of transactions to invalidating the incorporation documents of a legal person and/or decisions of the general meeting of the partnerships is set.

Key words: nullity of transactions, void transactions, illegality of transactions, valid, entered into, lawful. 


\section{INTRODUCTION}

Transactions are one of the most common grounds for creation, modification and termination of civil matters. That is why determination of specific features of valid transactions is very important.

There are gaps in legislation and contradictions in the regulation of invalidity of transactions, starting from terminology governing invalid transactions.

It is very important to make correlation between invalid, void and illegal transactions, that will be done in this essay. It establishes the specifics of invalid transactions, that demarks them from other similar legal categories. The essay discloses gaps and contradictions in the legislation of Ukraine, while pointing out different approaches of the application of law by the courts when it comes to the nullity of transactions, as well as offers solutions as to its improvement.

\section{DEFINITION OF A TRANSACTION AND ITS SPECIFICS COMPARED TO OTHER LEGAL NOTIONS}

According to section 202 (1) of the Civil Code of Ukraine (hereinafter referred to as 'the CC') a transaction is defined as an action of a person, aimed at obtaining, modifying or terminating civil rights and duties. ${ }^{1}$

In order to define the specifics of this type of legal fact, as well as in order to distinguish it from other similar legal notions, it is necessary to determine the main features of transactions.

As such, the first characteristic is the fact that a party to a transaction has its own will to accomplish an act of transaction, which will does not normally depend on the will of other persons. This is how the principle of the freedom of contract comes into play. However, in order to make a transaction, it is not enough to have an inner will to reach a legal result. It is necessary to demonstrate in front of others such inner will of a party to a transaction.

Subject of a transaction can be any physical or legal person whose civil capacity necessarily includes accomplishing such acts. Also, a state, territorial communities, Autonomous Republic of Crimea, could be subjects of transactions, as they have a legally recognized status of a participant of civil relations (sec. 2 of the CC of Ukraine), subject to limitations imposed by the laws of Ukraine.

Hence, a transaction shall not be considered legally concluded if the outer expression of the will of a party does not adequately reflect its inner will.

The second essential characteristic of a transaction is its aim of attaining a specific legal result, as directly appears from sec. 202 (1) of the CC of Ukraine. However, this feature is also present with other types of legal facts - legal acts. For instance,

1 Civil Code of Ukraine of 16 January $2003<$ http://zakon1.rada.gov.ua/laws/show/435-15> accessed 22 February 2019. 
such acts as creation of literary or art works, inventions, as well as other products of intellectual and creative work (sec. 11 (2) of the CC of Ukraine).

Lawful acts which are purely technical by nature cannot be qualified as transactions (for example, driving one's own automobile, personal agricultural work by a farmer, construction work carried out personally by a homeowner, consumption of groceries). At the same time, acts of technical (physical) nature may support making of or carrying out a transaction. For instance, delivery of the sold goods by the seller to the buyer using seller's own means of transportation. However, handing over of these goods by the seller to the buyer by means of a bill of lading may be considered an additional transaction to the principal transaction of sale.

Acts of state authorities and local government, judicial decisions may not be considered transactions, as they are constituting governing powers delegated to them by the State in accordance with the Constitution of Ukraine.

Acts (orders, resolutions, etc.) of the executive structures of legal persons, aimed at the governance of the legal person and organisation of its activity do not constitute a transaction. An issue of the legal nature of the incorporating documents, articles of incorporation, minutes of the meeting of the legal person is rather complex. According to sec. 153(2) of the CC, if a joint-stock company is created by several persons, they conclude among themselves an agreement that establishes the carrying out of their joint activity as to creation of the company, which is not considered an incorporation document of a joint-stock company. At the same time, such an agreement is a transaction.

There are two positions in Ukrainian civil law when it comes to the legal nature of incorporation documents: 1) articles of incorporation are a local regulatory act, not a transaction; 2) articles of incorporation, rules and resolutions are a type of acts made by their corresponding bodies and contain corporate norms, which, in turn, are part of social norms.

Absence of a clear definition of the legal nature of the articles of association in the governing law led to the necessity to formulate legal views of the higher judicial instances in Ukraine, which could be summarized as follows.

According to clause 14 of the Order of the Plenum of Supreme Court of Ukraine dated 24 November2008 No 13 'Articles of incorporation of a legal person as provided in sec. 20(2) of the Commercial Code constitute an act which determines the legal status of the legal person, given that they contain mandatory rules in regard to its shareholders, its officers and other workers, as well as determines the order of ratification and modification of the articles of association.

Grounds of invalidity of the acts, including the articles of incorporation, are as follows: its non-conformity to the current legislation and/or specified by law jurisdiction of the authority that issued (approved) such an act, as well as running contrary to the rights and legally protected interests of a claimant that occurred following such issuance or approval.

Articles of incorporation are not a one-party transaction, as they are approved (modified) by a general assembly of participants (founders, shareholders), while the 
latter constitutes neither subject of law nor authority that represents the partnership. Articles of incorporation cannot be classified as a contract, as they are approved (modified) by the majority of votes of shareholders or simple majority of votes of participants of a partnership, rather then by an agreement of all participants of a partnership (founders, shareholders) товариства, (sec. 42, 59 of the Law of Ukraine on commercial partnerships).

Hence, provisions as to invalidity of transactions do not apply to disputes as to invalidating articles of incorporation.

Similar position is found in clause 5.3. of the Order of the Plenum of Resolution of the Plenum of the Supreme Commercial Court of Ukraine dated 25 February 2016 No 4, according to which 'articles of incorporation are a local normative act, not a transaction, hence sections 203 and 215 of the CC of Ukraine that govern grounds of invalidity of transactions do not apply thereto.'2 However, this position of the Plenum of the SCCU does not fully correspond to the position of the SCU, nor does it correspond to the norms of the Constitution of Ukraine that define the authorities capable of passing normative acts.

We believe, when dealing with this issue, it is necessary to follow the Ruling of the Constitutional Court of Ukraine in the case of a constitutional request by the Limited Liability Partnership 'Likhner Beton Lviv' for the official interpretation of the provisions found in sec. 58 (4) and 64 (1) of the Law of Ukraine on 'Commercial Partnerships' dated 5 February 2013. In paragraph 3.1. of this Ruling of the CCU it is stated that 'an incorporation document of a Partnership is its Articles of Incorporation (section 143 (1) of the CC of Ukraine, section 80 (1) of the CC of Ukraine, 4 (1) of the Act). Articles of incorporation constitute a local legal act and all participants must follow and execute it.' ${ }^{3}$ It may be assumed that the Ruling of the CCU refers to a 'local legal act' for a reason, as opposed to a 'local normative act', as we believe they are not synonymous.

Given the above, it is our view that the legal definition of the articles of incorporation could be that of a local legal act, that establishes legal personality of a legal person and its scope of use by authorised bodies and persons, as well as establishes general rules of execution of labour and corporate rights and obligations of participants and officers of a legal person. At the same time, features of normative-legal act are also common for model and typical articles of incorporation, which are approved by the authorised bodies of the state.

Decisions of the general meetings of a joint-stock company to liquidate the partnership, as well as decisions aimed at creation, modification or termination of civil rights and duties of shareholders contain features of transactions.

2 Order of the Plenum of the Supreme Commercial Court of Ukraine of 25 February. 2016 No 4 <http://zakon.rada.gov.ua/laws/show/v0004600-16> accessed 22 February 2019.

3 Ruling of the Constitutional Court of Ukraine in the case of a constitutional request by the Limited Liability Partnership 'Likhner Beton Lviv' for the official interpretation to of the provisions found in sec. 58 (4) and 64 (1) of the Law of Ukraine on 'Commercial Partnerships' of 5 February 2013 <https://zakon.rada.gov.ua/laws/show/v001p710-13> accessed 23 February 2019. 
At the same time, jurisprudence has a wide opposing view as to the decisions of the general meetings of the participants (shareholders) and other organs of commercial partnerships, considering them as acts, 'given such decisions lead to creation of legal consequences, aimed at regulating commercial relations, and are mandatory for subjects of such relations.' Grounds of their invalidity may be: running contrary to the requirements of laws and/or incorporation documents during the convocation and holding of general meetings of the partnership; depriving a shareholder (participant) of the partnership of its right to take part in general meetings; violation of rights or legal interests of a shareholder (participant) of a partnership contained in a decision of a general meeting. ${ }^{4}$

Third feature of a transaction is making a transaction in accordance with the legal requirements, as it belongs to a category of lawful legal facts.

These requirements are formulated in sec. 203 of the CC, according to which:

'1. Contents of a transaction cannot contradict this Code, other acts of civil legislation and moral principles of the society.

2. A person that effects a transaction shall have a required scope of civil capacity.

3. Expression of the will of a participant to a transaction shall have to be free and shall correspond to his/her inner volition.

4. A transaction shall be effected in the form established by the law.

5. A transaction shall be aimed at realistic occurrence of legal consequences stipulated by it.

6. A transaction effected by parents (adoptive parents) cannot contradict the rights and interests of their infants, minors or disabled children. ${ }^{5}$

However, this rule has exceptions, established by the law. For instance, sections of the CC that allow transactions with certain defects to be legalized (made lawful) in a judicial manner or that allow for them to be approved by authorised persons, defined by the law (sec. 220, sec. 221, sec. 226 of the CC). Hence, the statement by some Ukrainian authors that believe that a transaction is 'necessarily a lawful act' cannot be supported.

Besides, a transaction that does not meet all the listed requirements is not invalid. For example, according to sec. 218 of the CC of Ukraine, if the parties do not conform to the legal requirements of a written form of a given transaction, as a rule such transaction is not invalid. Moreover, the legislator may provide for a possibility of proving the fact of making a transaction by witness testimony.

Transactions differ from other legitimate legal facts by their features, as grounds for creation of civil rights and duties.

4 Order of the Plenum of the Supreme Court of Ukraine of 24 October2008 No 13 'About Practice of Consideration of Corporate Disputes' p. 17 < https://zakon.rada.gov.ua/go/v0013700-08> accessed 23 February 2019.

5 Civil Code of Ukraine. 
Only if a transaction meets the listed requirements fully, its validity is secured, so as to obtain the given legal result which is recognized by other participants of civil relations. Such conformity of a transaction to the requirements of sec. 203 of the CC is presumed, given that according to sec. 204 of the CC a transaction is legitimate, unless the law directly establishes its invalidity or the court invalidates it.

\section{EDITORIAL AND CONTEXTUAL ISSUES WITH THE PROVISION OF SEC. 204 AS TO THE PRESUMPTION OF LEGITIMACY OF A TRANSACTION}

Based on the title of section 203 of the CC -'General Requirements Necessary for Validation of a Transaction', a conclusion can be made that non compliance with the requirements listed it the six paragraphs of this section should lead to the legal result of a void transaction. Instead, sec. 204 of the CC confirms the presumption of legitimacy (rather then validity) of a transaction, which is not used unless its invalidity is not directly provided for by law or the court invalidates it.

The provisions under review have the following illogical and contradictory issues: 1) definition of the legal meaning and the conditions of validity of a transaction in the absence of conditions of its invalidity; 2) the law provides for a presumption of validity of transactions and does not deal with the legal consequences of an illegitimate transaction; 3 ) absence of definition in law of the correlation between the terms 'validity', 'illegitimacy', 'invalidity'.

We believe that validity of a transaction refers to the latter having legal features that insure legitimacy of the acts of its party (parties) and a legal effect of the accomplished legal result.

Legitimacy of a transaction should be defined as conformity of its integral parts (subjects, form, content etc) to the general requirements of the sec. 203 of the CC and other special provisions of the law, which secure the transaction's own validity. Hence, lack of legitimacy of a transaction leads to its invalidity. Therefore, there is a certain correlation between the validity and legitimacy of a transaction, that reflects dependency of the act of validity from its legitimacy. Normally, the term 'validity' is used to establish the moment of entering into force of a legal act, for instance, the subsection 1 of the Final and Transitional Provisions of the CC state, that 'This Code enters into effect on January 1, 2004. Therefore, it would be logical to view the notion of 'validity' in terms of establishing of the moment of entry info effect of a transaction and/or normative-legal act.

\section{TERMINOLOGICAL ISSUES WITH THE LEGAL STATUS OF PERSONS, THAT ENTERED INTO AN INVALID TRANSACTION.}

Provisions of section 16 of the CC of Ukraine dealing with persons who entered into a valid and invalid transaction use one term - parties. Usage of such a term in regards to the persons who made a valid transaction is a legally correct and logical method of determining their legal status as subjects of a legitimate civil relation. However, 
doubts occur as to whether persons who entered into a transaction invalidated by the court may be described as parties. We believe such persons should not have the status of a party. However, civil legislation tends to use the term 'party'. For instance, according to sec 231 (1) of the CC a transaction concluded by a person against his/ her true will due to the application of physical or psychological force by the other party or by the other person, shall be invalidated by the court.

Other terms are also used - 'person - participant'. For instance, Interpretation of the Supreme Arbitration Court of Ukraine dated March 1999 'On some Practical Issues of Dispute Resolution, Related to Recognition Contracts as Invalid' (no longer valid $)^{6}$, used to state that 'an interested person - participant to a contract invalidated by the court is not deprived of its right to demand performance by its counteragent from a third person that is not party to such a contract, as it was obtained without due legal grounds'. We believe that such terminology does not allow conferring a legal status of a party to a valid transaction, to a person involved in an invalid transact. Other acts of the supreme judicial authorities in Ukraine use terms 'parties' ${ }^{7}$ and 'participants' ${ }^{8}$ of an invalid transaction.

We believe it is more appropriate to use the term 'participant' of an invalid transaction, then the term 'party'.

\section{USAGE OF THE TERM 'INVALIDITY' IN OTHER LEGAL CONSTRUCTIONS}

As mentioned above, chapter 16 of the CC of Ukraine deals with the grounds and consequences of invalidity of transactions in relation to the consequences of a failure to follow the conditions of validity of transactions.

At the same time, civil legislation regulates cases of invalidity of other related legal constructions, to which chapter 16 does not apply, as their legal nature is different. For instance, according to sec. 1301 of the CC of Ukraine, a court may declare invalid a certificate of right of inheritance. It is obvious, that a certificate of right of inheritance is different in legal nature from a transaction.

A certificate of right of inheritance is, in our opinion, a legalizing document affirming the presumption of a lawful acquisition of the right of ownership by its holder. Certificate of right of ownership, certificate of right to a part of family patrimony, state act of ownership of a parcel of land can be classified as such legalizing documents. That being said, invalidating such documents is done

$6 \quad$ Interpretation of the Supreme Arbitration Court of Ukraine of March 1999 'On some Practical Issues of Dispute Resolution, Related to Recognition Contracts as Invalid' (no longer valid) $<$ http://zakon.rada.gov.ua/laws/show/v_111800-99> accessed 23 February 2019.

7 Order of the Plenum of the Supreme Court of Ukraine of 6 November 2009 No 9`On Court Practice of Civil Cases Consideration on the Recognition of Contracts as Invalid' <http://zakon. rada.gov.ua/laws/show/v0009700-09> accessed 23 February 2019.

8 Order of the Plenum of the Supreme Court of Ukraine of 29 May 2013 No 11 'On Some Issues Related to the Recognition of Commercial Contracts as Invalid' <http://zakon.rada.gov.ua/laws/ show/v0011600-13> accessed 23 February 2019. 
according to special provisions such as those contained in section 1301 of the CC of Ukraine establishing procedure of invalidating a certificate of the right of ownership of inheritance.

Invalidity as a sanction is also applied to decisions of state authorities and municipal bodies. For instance, according to sec. 21 of the Land Code of Ukraine non-compliance of the order of creating and modification of the primary usage of the land constitutes a ground of invalidity of decisions of state authorities and local municipalities regarding granting of land parcels to citizens and legal persons. Same as in the case above, rules applicable to the invalidity of transactions do not apply to decisions of the mentioned authorities and municipalities. However, judicial practice does not always follow this definition. For instance, Resolution of the Supreme Court of Ukraine dated 14 May 2014 is entitled 'On Declaring Illegal of the Decisions of Village Council, Declaring Invalid of a State Act of Ownership of a Parcel of Land and Abolishment of the State Registration of the Right of Ownership of a Parcel of Land', despite the fact that the resolution correctly refers to sec, 213 of the Land Code of Ukraine containing such terms as 'invalidating decisions', 'invalidating registration'. It is possible to assume that the title of the Resolution is explained by an incorrect usage of terminology by the claimant of the lawsuit in the given case. However, even under such circumstances the Supreme Court of Ukraine should have expressed its legal position as to the correlation of the notions of 'invalidity' and 'illegality', given that, in our opinion, they are not synonymous and may lead to different legal consequences. It is to be noted that the mere fact of declaring illegal of a decision of a state authority or a local municipality does not carry a binding act and does not determine certain legal consequences that would occur should a court declare such decisions illegal. Examples of such consequences could be restoration of the prior state of the subjects to an illegal decision or abolishment of state registration of the right of ownership of a parcel of land. This is how sec. 393 of the CC of Ukraine deals with a similar issue, it provides that a legal act of a state authority, an authority of the Autonomous Republic of Crimea or a local municipality that run contrary to law and breach the rights of an owner, may be declared illegal by a court and abolished upon the property owner's claima, moreover, property owner has the right to demand re-establishment of the prior state that had existed before adoption of the act, or claiming material and moral damages in case such re-establishment is not possible. Formulation of sec. 393 of the CC of Ukraine is constructive, as not only it provides for the possibility to declare a legal act illegal, but also establishes specific legal consequences, up to its abolishment, which are common to the provisions as to invalidity of transactions and its legal consequences. It would be logical to use such approach in provisions dealing with invalidity of legalizing documents dressed as certificates, or other formats, legal acts or decisions of state authorities or municipal bodies, despite the fact that they are not transactions within the meaning of provisions of chapter 16 of the CC of Ukraine.

Apart from the terms unconcluded or invalid, legislation uses such other terms as - 'voidance of administrative agreements' (sec. 19 of the Code of Administrative Proceedings of Ukraine), unlawfulness of normative-legal acts (illegality or nonconformity to a legal instrument of higher legal hierarchy) and voidance as its 
consequence (sec. 264 of the CAPU). However, given that the nature of such acts is not that of civil law, provisions of the latter do not apply to such acts when it comes to declaring them invalid.

\section{DEFINITION OF AN INVALID TRANSACTION AND ITS CORRELATION WITH A VOID TRANSACTION}

Sec. 215 of the CC of Ukraine lacks definition of an invalid transaction, rather it establishes grounds of invalidity of transactions. For instance, first paragraph of the above section states: 'A ground for invalidity of a transaction shall be noncompliance of a party (parties) with the requirements established in paragraphs $1-3,5$ and 6 of Article 203 of this Code at the moment of the transaction concluding'

Contrary to the new CC of Ukraine, the CC of the USSR dated 1963 contained a laconic definition of an invalid transaction (agreement), according to which an agreement that runs contrary to law is invalid ${ }^{9}$ (sec. 48 (2). However, such definition may not be used in modern times as chapter 16 of the CC of Ukraine, non-compliance of the law is only one of the grounds of invalidity of transactions (ex: sec. 228 of the CC).

It is difficult not to point out a certain legal inconsistency of the notion of an 'invalid transaction', since given its nature of a legal fact (it is declared so in legislation), then logically speaking we should must also consider actions of a party (parties) as invalid, which is contrary to the laws of objective reality. Although such actions are not lawful, they may not be classified as invalid in principle (non-existing in fact), as they did occur. Their unlawful (illegal) nature is another subject, they should be considered void and not leading to the desired legal consequences, other than those that according to sec 216 (1) of the CC relate to its invalidity.

Invalidity of a transaction results from a wrong-doing by its participants at the time of them carrying out the unlawful acts. This means that inadequate performance of the duties of a transaction by its parties, or a wrong-doing by its parties following the conclusion of a transaction, may not form a ground of its invalidity. This rule is undisputed din civil law and jurisprudence.

For instance, a decision of the District Court of Starokyivsk of the City of Kyiv dated 30.09.1999 invalidated an agreement of a lifetime maintenance on the ground of improper performance of the apartment buyer of its obligations before the seller. This decision was declared in force by a court panel in civil matters of the Kyiv city court (resolution dated 08.12.1999 ). Deputy Chairman of the SCU applied to dismiss these judicial decisions to the Presidium of the Kyiv City Court, stating, among others, that non-performance by the buyer of its duties under a contract may not lead to its invalidity, but rather may constitute a ground for terminating a contract upon request of the seller. The application to dismiss was allowed by the Resolution of the Presidium of the Kyiv City Court dated 09.04.2001.

$9 \quad$ Civil Code of the USSR of 1963 <http://zakon.rada.gov.ua/laws/show/1540-06\#o193> accessed 23 February 2019. 
At the same time, some normative legal acts contain provisions that are contrary to the stated rule, creating difficulties in their application in jurisprudence.

For instance, the Law of Ukraine 'On Privatization of the State and Communal Property' states the following provisions as to the grounds of declaring invalid a contract of sale and purchase of the state or communal property via privatization:

May be terminated or invalidated by a court, upon a request of one party to a contract of sale and purchase, including by a court decision, in the event of nonperformance by the other party of its obligations under the contract of sale and purchase within the specified term (sec. 26(9);

- Privatization agency should demand from the new owner performance of the obligations under the contract of sale and purchase of the privatization objet, and in the case of non-performance apply sanctions to the former in accordance with the law, as well as protect interest of the state or territorial community in other manner, including filing a legal claim as to terminating the contract of sale and purchase of the object of privatization or declaring it invalid (sec. 27 (11). ${ }^{10}$

In our opinion, this issue can only be solved by modifying the Law of Ukraine «On privatization of state and communal property» in regards to a provision that would allow termination of the contract of sale and purchase of the object of privatization upon the claim of one of the parties or of the authority mandated with management of the objects of state property upon a ruling of a court in the event of nonperformance of the other party of its duties under the contract of sale and purchase, or in the event of being declared invalid following non-compliance with the legal requirements during the contract's conclusion.

\section{GROUNDS OF INVALIDITY OF TRANSACTIONS: DEFINITION AND ISSUES IN ITS FRAMEWORK}

The main issue in the area of invalidity of transactions is defining the grounds of invalidity in order to choose the most appropriate civil remedy and the proper formulation of the claims.

As mentioned before, sec. 215 (1) of the CC provides that non-compliance of a party (parties) with the requirements established in paragraphs 1-3, 5 and 6 of Article 203 of this Code at the moment of concluding the transaction shall be a ground of its invalidity. It should be noted that sec. 203 formulates such conditions of validity rather directly, and they cannot receive wide interpretation. The conditions are as follows: 1) Contents of a transaction cannot contradict this Code, other acts of civil legislation and moral principles of the society; 2) required scope of civil capacity of a person that effects a transaction; 3) Expression of the will of a participant to a transaction being free and corresponding to his/her inner volition; 4) Aim of a transaction at realistic occurrence of legal consequences stipulated by it; 5) A

10 Law of Ukraine 'On Privatization of the State and Communal Property'<https://zakon.rada.gov. ua/laws/show/2269-19> accessed 23 February 2019. 
transaction effected by parents (adoptive parents) cannot contradict the rights and interests of their infants, minors or disabled children.

Particular attention must be made in correctly formulating the grounds of invalidity in a given claim while using invalidity of transactions as a civil remedy. For instance, in the case of a null transaction, according to sec. 215 of the CC claims must state a demand to apply consequences of invalidity of a null transaction, without asking to declare such transaction as invalid. This flows from the content of sec. 215 (2), according to which a transaction is null, if invalidity of the transaction is proclaimed by law, in which case declaration of invalidity by a court is not required.

The above-mentioned provision implies two important legal positions. Firstly, transactions are declared null only directly by law, which does not have a general list of specific null transactions, which are pronounced as such in specific sections of the CC and other legal instruments. Secondly, nullity of a transaction provided by the law does not require a declaration of invalidity of the transaction in accordance with sec. 215 of the CC. In other words, there is no necessity in declaring the null transaction as invalid by the court. This provision was viewed in a mixed manner by the civil doctrine and interpreted differently in jurisprudence.

At the same time, the legislator does not follow the rule contained in sec. 215 of the CC throughout the Code neither. For instance, sec. 228, that deals with legal consequences of concluding a transaction that is contrary to the public order and is null, provides that a transaction contrary to the requirement of agreeing with the interests of state and society or moral principles of society may be declared invalid. Therefore, despite the nullity of a transaction that is against public order, it is necessary to declare it invalid in order to resort to the remedies provided in sec. 228 of the CC, which contextually and literally conflicts with sec. 215 (2) of the CC that states that invalidating a null transaction by the court is not required.

It is our opinion that legislator's decision to insert a presumption of invalidity of a null transaction into this section did not purport to establish the fact of nullity outside of the court, but rather to empower the court to confirm presence of irregularity as such that does not require evidence of legal irregularity of a null transaction in accordance with all the procedural steps, allowing therefore to resort to the available legal remedies. AT the same time, most null transactions against public order may not be considered invalid without a judicial confirmation of this fact both in terms of material and procedural law. Optional nature of declaring a transaction that is against public order null outside the court in the legal provision contained in sec. 215 of the $\mathrm{CC}$ and its interpretation by higher courts is deprived of legal logic and does not assist in removing the violation of the requirements of the law. An interesting idea has been put forth in the 'General concepts of the courts' practices in the field of invalidating transactions' dated 24 November 2008, which state that a claimant may address the court with a demand to confirm nullity of a transaction if there is a dispute as to presence of absence of such fact; courts may be addressed with claims of invalidating a disputed transaction and applying the appropriate remedies, as well as claims confirming nullity of transactions and applying the appropriate remedies. In this case, authors of the General Concepts believe, with reason, that courts deal with claims as 
to 'confirmation of nullity of a transaction', rather then 'declaring a transaction as null'. Unfortunately, the Supreme Court of Ukraine, in its Resolution of the Plenum dated 6 November 2009 №9 'On court's practices in the field of civil claims to invalidate transactions' did not take this legal position.

Final dots can only be placed by modifying sec. 215 of the CC of Ukraine accordingly.

\section{DECLARING TRANSACTION AS UNCONCLUDED AS A LEGAL REMEDY}

In order to answer the issue in question it is necessary to look into the norms of the Civil and the Civil Procedure Codes of Ukraine (hereinafter referred to as 'CPC') the dealing with the grounds for application of a remedy. For instance sec. 16 of the CC contains an non-exclusive list of remedies of civil rights and interests, among which appears invalidating transaction. Paragraph 2 of this section (modified by the Law dated 3 October 2017) establishes a special warning, according to which a court may protect the civil right or interest using another remedy if so stipulated contractually, legally or judicially in cases defined by the law. The new version of this section allowed for a possibility of using another remedy to protect civil rights and interests, besides those mentioned in the contract or the law, which is a remedy chosen by court. Sec 5(2) of the CPC also considered this special circumstance, drafted as follows: 'In cases where the law or the contract do not provide for an efficient remedy of an infringed, undeclared or disputed right, freedom or interest of a person applying to the court, the latter may establish in its decision a remedy that does not run contrary to law, in accordance with the claims laid out in the application. ${ }^{11}$ Analogous norm is found in sec. 5 of the Economic Procedural Code of Ukraine. Adoption of this provision is progressive and positive, as in the past the Constitutional Court of Ukraine annulled court decisions of the lower jurisdiction on the ground of them using a remedy not specified by law.

Hence, the modifications allow the court to use the most efficient remedy of protecting the infringed civil rights in those cases where such remedy is not offered by the law. Such remedies may be offered as, inter alia, invalidating a transaction, proclaiming it as unconcluded etc.

At the same time, Plenum’s Resolution № 9 makes an opposite conclusion : requirement to declare a transaction (contract) as unconcluded does not fall within the possible remedies of protection of civil rights and interests established by law. Courts may deny such claims. In such cases, only claims mentioned in chapter 83 of Book 5 of the CC may be made. ${ }^{12}$

11 Civil Procedure Code of Ukraine of 2004 (with amendments) <https://zakon.rada.gov.ua/laws/ show/1618-15> accessed 23 February 2019.

12 Resolution of the Plenum of 06 November 2009 No9 'On Court]s Practice in the Field of Civil Claims to Invalidate Transactions' <https://zakon.rada.gov.ua/laws/show/v0009700-09> accessed 23 February 2019. 
It is our position that to solve this issue we should first analyze the current legislation. For instance, according to sec. 638 (1) of the CC of Ukraine, an agreement shall be concluded if the parties have duly reached consensus on all its essential conditions. A similar provision is found in sec. 180 of the Economic Code of Ukraine, according to which a business agreement is deemed to be concluded if the parties reach an agreement in accordance with the procedure and the forms envisaged by law in regard to all the material terms thereof. As such, if we follow legal logic, we can easily come to a conclusion that a concluded agreement should have a corresponding notion of an 'unconcluded agreement', given that the legislator recognizes the fact of existence of both valid and invalid transactions. Hence, it is possible to encompass a claim of non-conclusion of an agreement due to the lack therein of its essential term to provide for an appropriate remedy of protecting civil rights and interests, despite the lack of such remedy in the list established by sec. 16 of the CC, given that according to this section a court may protect civil rights and duties in other manner than that established by contract or by law.

If we consider the current formulation of sec 181 (7) of the Economic Code of Ukraine, we would come to this conclusion, it states 'If the parties fail to agree on all the material terms of a business agreement, this agreement shall be deemed as unconcluded (the one that was never concluded). At the same time, a conclusion can be made based on this provision, that only a business agreement where parties failed to agree on all the material terms, rather than only one or a few of them, shall be deemed unconcluded.

Similar provision is also found in other normative-legal acts, for instance in General terms of conclusion and performance of subcontracts in construction, approved by the Order of the Cabinet of Ministers of Ukraine on August 1, 2005 No 668. (para. 12) ${ }^{13}$. Law 'On the rental of land' provides for such a remedy as declaration of conclusion of a contract of rent by the court in the event of a dispute as to the conclusion of contract by its parties (sec. $\left.8^{2}\right) .{ }^{14}$

At the same time, absence of a material term in the contract shall not be regarded as an absolute ground of its non-conclusion. For example, it is not reasonable to view the contract as unconcluded if one or a few material terms are missing, in the event of a full performance of the contract by its parties, including a term that was not provided for.

Mutually exclusive statements of the Supreme Court appear contradictory insofar as stating that only a concluded agreement (transaction) may be declared invalid, and then establishing that lack of a material term violates requirements of sec. 203 of the CC of Ukraine, which constitutes on its own a ground of invalidity of a contract.

Legal doctrine is lacking an integral and conceptual approach when it comes to interpreting definitions of invalidity and non-conclusion of agreements, and to

13 Decree of the Cabinet of Ministers of Ukraine of 1 August 2005 No 668, para. $12<$ https://zakon. rada.gov.ua/laws/show/668-2005-\%D0\%BF> accessed 23 February 2019.

14 Law of Ukraine 'On the rental of land' <https://zakon.rada.gov.ua/laws/show/161-14/> accessed 23 February 2019. 
determining their legal nature and legal consequences. The issue had been subject of relatively quiet discussions in civil and economic legal doctrine with two contrary approaches.

Authors of the first approach believe that absence of a material term in an agreement is a ground of its invalidity with the appropriate consequences. Followers of the second approach believe that in the event of a finding that the agreement is unconcluded due to lack of a material term, provisions as to unjust enrichment should apply in the event of handing over the property by the counteragents, while in the event of loss or damage of property, - a damages claim.

In order to avoid such an absurd situation, it is necessary to differentiate the legal nature of the violation of requirements listed in sec. 203 of the CC, compliance thereof being essential to the validity of the transaction, and violation of the requirements of sec. 638 of the $\mathrm{CC}$ which are required for an agreement to be concluded.

Correspondingly, the first violation may serve as a ground of invalidity of the transaction, while the other as a ground of its non-conclusion. The Supreme Court should consider reviewing its legal position as to the legal consequence of a lack of material terms in a contractual transaction and the legal consequences of an unconcluded contractual transaction. Of course, review of its legal position by the Supreme Court will not resolve the entire issue. In any case, it is suggested to perform the relevant legislative corrections. For instance, sec. 638 of the CC of Ukraine should be complemented by a third paragraph of the following content: 'In the event of lack of a material term in the agreement, such agreement may be declared by the court as unconcluded and legal consequences mentioned in chapter 83 of this Code should be applied'.

Moreover, parties may stipulate the most efficient remedy directly in their agreement. Hence, the main accent in establishing a possibility of dealing with these cases is the remedy's goal to protect the infringed, disputed or unrecognised rights or interests, as well as impossibility to select another remedy.

\section{CONCLUDING REMARKS}

Main features of transactions that help differentiate them from other types of legal facts are: fact that a party to a transaction has its own will; parties to a transaction may be all subjects of civil law within their jurisdiction; aimed at occurrence of a certain legal consequence; carrying out the transaction according to the requirements of the law.

Articles of incorporation (articles of association, except for the articles of association of a partnership) are not a type of transactions, but a local legal act that determines the legal status of a legal person and its modalities of use by the authorised bodies and persons, as well as establishes general terms of carrying out the labour and corporate rights and obligations of the participants and officers of the legal person. 
Based on the above, it is important to point out impossibility to use provisions as to invalidity of transactions to invalidating the incorporation documents of a legal person and/or decisions of the general meeting of the partnerships. In presence of the grounds stipulated by law, they may be invalidated according to special provisions.

Civil legislation also provides for a mechanism of invalidating other types of legal facts, besides transactions. For instance, such facts as certificates of the right of inheritance, certificates of the right of ownership of a part of family patrimony, a state act of the right of ownership of a parcel of land, decisions of the state authorities and local municipalities etc. Same as in the prior case, provisions of invalidity of transactions do not apply to invalidity of such certificates and decisions.

It is important to differentiate notions of validity and legitimacy of transactions as follows. Validity of a transaction refers to the latter having legal features that insure a lawful nature of the acts of its party (parties) and a legal effect of the accomplished legal result. Whereas legitimacy constitutes conformity of its integral parts to the general requirements of sec. 203 of the CC and other special indications of the law, which ensure validity of the very transaction. Hence, these notions are related, and validity depends on its legitimacy.

When determining the subject of a transaction, it is important to use the term 'party', and when it comes to an invalid transaction, the term 'participant' of an invalid transaction.

When declaring a transaction invalid, it is necessary to establish at least one violation of the terms of validity of transactions.

Invalidity of transactions is the result of a violation that occurred during the carrying out of unlawful acts by its participant(s). This means that inadequate performance of the obligation by the parties to a transaction, or their violation after the conclusion of the transaction cannot be a ground of its invalidity. In relation thereto, it is important to describe as legally incorrect provisions of the Law of Ukraine on 'Privatization of the State and Communal Property', which provides for a possibility to declare invalid a contract of sale and purchase in the field of privatization, in the event of non-performance or inadequate performance of its terms, besides the possibility to terminate the contract.

An invalid transaction is an act of one or several persons - subjects of civil law, aimed at acquisition, modification or termination of civil rights with such a violation of the law that legal consequences of lawful legal facts would not be allowed to occur, with the exceptions directly provided in the law, for instance, in presence of the grounds of invalidity with defects of actions, or using a mechanism of sanitation (healing) of the actions performed defectively by way of declaring them invalid in court. 